\title{
Reading Preferences across Genders of Undergraduate EFL Students in Indonesia
}

\author{
A. Dzo'ul Milal ${ }^{1}$, Raudlotul Jannah ${ }^{2}$, Sufi Ikrima Sa'adah³, Andini Anugrah Fitria4 \\ ${ }^{1}$ UIN Sunan Ampel Surabaya.e-mail:dzoulmilal@uinsby.ac.id \\ 2 UIN Sunan Ampel Surabaya.e-mail: j.brilianty@gmail.com \\ 3UIN Sunan Ampel Surabaya.e-mail: sufiikrimasaadah@gmail.com \\ 4 UIN Sunan Ampel Surabaya. e-mail: andinifitria21@gmail.com
}

\begin{tabular}{|c|c|}
\hline ARTICLE INFO & ABSTRACT \\
\hline $\begin{array}{l}\text { DOI: } \\
\text { http://dx.doi.org/10.21093 } \\
\text { /ijeltal.v6i1.918 }\end{array}$ & $\begin{array}{l}\text { Due to pandemics, students carry out their studies from home. They have } \\
\text { more leisure time and are freer to do activities. In such a condition, questioning } \\
\text { students' commitment to reading to learn becomes relevant. The question is } \\
\text { whether and to what extent the students do the reading activity, what they } \\
\text { read, and whether their preferences are different based on their genders. This } \\
\text { topic is inconclusively studied, especially in the context of EFL. Therefore, it } \\
\text { seems important to conduct a study on this topic because the results might } \\
\text { raise the effectiveness of teaching EFL. This study is a descriptive survey } \\
\text { revealing students' reading preferences to spend their leisure time based on } \\
\text { gender differences. The subjects are undergraduate EFL students aged 19-23 } \\
\text { years who study at the English Department in Indonesia. The data were } \\
\text { collected by a questionnaire consisting of closed and open items. The } \\
\text { responses were tallied, calculated, and tabulated. The findings show that } \\
\text { female respondents favored reading more than males. Both genders tend to } \\
\text { prefer reading social media to spend their leisure time. Female respondents } \\
\text { are more likely to read e-books, while male respondents are more into the } \\
\text { printed books. They do extensive reading to get knowledge more than to get } \\
\text { pleasure. Although they are EFL learners, they prefer reading the sources in } \\
\text { their native language because it is more accessible than in the target } \\
\text { language. The reasons underlying those findings and pedagogical } \\
\text { implications are also described at the end of the article. }\end{array}$ \\
\hline
\end{tabular}

How to cite:

Milal, A.D., Jannah, R., Sa'adah, S.I., Fitria, A.A.. (2021). Reading Preferences across Genders of Undergraduate EFL Students in Indonesia. Indonesian Journal of English Language Teaching and Applied Linguistics, 6(1), 141-153

\section{Introduction}

Reading is an essential skill that needs to be mastered not only by English Foreign Language $(E F L)$ students but also by other students regardless of their field of studies. As one of language-related activities, reading is important to increase knowledge and improve language competence. For EFL students, reading can be used to promote language skills, 


\section{A. Dzo'ul Milal et al.}

such as improving pronunciation (through reading aloud), reinforcing grammar, increasing vocabulary, recognizing verbal symbols, gaining insights, and getting pleasure (Krashen, 1994). Furthermore, reading comprehension and reading mastery are fundamental requirements for academic success. Students cannot separate their academic routines from reading, either for intensive or extensive reading. Due to its importance, it is relevant to inquire whether EFL students in Indonesia do the reading activity in their spare time and, if so, what their preferences in reading are.

Reading has been studied by many researchers. Concerning the factors that affect reading behaviors, Aharony \& Bar-llan (2018) revealed that relative advantage and comprehension affected the university students in Israel to prefer reading electronic materials. This study slightly diverges from Mizrachi et al. (2018), who conducted a survey on the reading format preferences and behaviors of university students world wide and found out that most of them prefer to read academic course materials in print, especially for longer texts. Similarly, Kurata et al. (2017) demonstrated that Japanese people favor printed books more than e-books despite their frequent usage of digital resources because of their perception that reading activities refer to reading printed materials. Furthermore, Zhang \& Kudva (2014) focused on unfolding the factors that influence readers to favor e-books over printed books. They found out that among the notable factors determining the adoption of e-books were the number of books to read, the individual's income, the frequency of reading, and internet use. Stokmans (1999) claimed that reading enjoyment affects learners' preference of reading behavior to spend their leisure time. Singer \& Alexander (2017) found out that reading digital media is preferable and increases better comprehension for undergraduate students. Karim \& Hasan (2007), when studying International Islamic university students in Malaysia, concluded that they spend much time reading newspapers, academic books, and websites. Reading has also become a significant activity during their leisure time.

Regarding the factors influencing reading competence, Akbari et al. (2017) tried to study reading and claimed that $L 2$ reading attitude contributed significantly to $L 2$ reading achievement. Chow et al. (2017) unraveled the contribution of foreign language motivation, learning strategies, and performance on foreign language reading and listening anxiety. Iwahori et al. (2008) claimed that extensive reading effectively increases the reading rate and language proficiency. This finding is confirmed by McLean \& Rouault (2017), who asserted that extensive reading improves the reading rate. Suk (2016) also stated that extensive reading effectively raises learners' reading comprehension, reading rate, and vocabulary acquisition. Alakawi (2017) argued that the strategy of teaching reading improves foreign language learners' reading comprehension. An almost similar finding is also claimed by Chen et al. (2013), who revealed that extensive reading using e-books effectively raises learners' reading attitude, reading comprehension, and vocabulary learning. On the other hand, Schiefele et al. (2012) asserted that reading motivation is influential on reading competence. Furthermore, Long \& Szabo (2016) stated that the use of e-readers affects young learners' reading motivation, attitude, and comprehension during the guided reading.

There are also some claims that extensive reading is beneficial in several ways. Delfi \& Yamat (2017) observe that extensive reading contributes to EFL learners' English competency. Furthermore, Lee et al. (2015) claim that extensive reading and translation activities improve learners' grammatical knowledge and language attitude. Ghanbari \& Marzban (2014) also state that extensive reading plays a role in vocabulary retention. Swalander \& Taube (2007) 
found that reading ability is also affected by self-regulated learning, motivation, learning strategies, attitude, and family factors. Lin (2014), on the other hand, carried out a study and advocated that mobile-assisted extensive reading is effective on reading achievement.

Some previous studies also tried to relate reading and genders. Even though there is no scientific evidence proving that males and females are biologically different in their ability and capacity for learning or reading, gender gaps stating that females are higher achievers in reading are well acknowledged. It has also been stereotyped that reading is more into feminine rather than masculine activity. Morrison (2017) reported that women read more books with an average of 14 books a year, compared to the average of men with 9 books a year. Not only do they differ in the numbers, but also in their reading habits and choices. Women prefer to read fiction books such as romance, mystery, thriller, and crime, while men tend to read nonfiction books such as history, biographies and memoirs, and also science fiction.

A study by Swalander \& Taube (2007) revealed that girls read better on narrative and expository texts. They had a more positive reading attitude and a more positive verbal selfconcept, whereas boys had a higher academic self-concept, self-efficacy, control expectation, more memorizing, elaboration, and instrumental motivation. Logan \& Johnston (2009) asserted that gender differences play a role in reading ability and frequency. Girls are claimed to have better reading comprehension ability and read more frequently and have a more positive attitude towards reading. They also claim that reading frequency is correlated with reading ability.

In large-scale international assessments such as PISA (Program for International Student Assessment) and PIRLS (Progress in International Reading Literacy Study), there had been consistent results from 2001 to 2016 proving that girls were more proficient than boys in their reading competence. Girls from 48 out of the 50 countries participating in PIRLS 2016 had higher average scores than boys, and boys did not have higher scores in any of those countries. Even though there was a trend indicating that good readers were internationally increased in 2016, the gender gap in reading achievement remained the same (Mullis et al., 2017). It is worth mentioning that PISA assessments were addressed to children and adolescents in their primary and secondary schools, not to adults. Therefore, in all PISA cycles, the studies consistently proved that gender differences in reading competence between children and adolescents were prominent, but not for adults. According to Thums et al. (2021), studies on continuous reading competence of adults were still rare and hardly found, although there have been some but not as many as studies on children reading competence. Another study similar to PISA, called PIAAC (Programme for the International Assessment of Adult Competencies), revealed less clear results on gender differences in adult literacy or reading (OECD, 2013).

Responding to such scarcity, Thums et al. (2021) explored further about gender differences and adults' reading competence with respect to specific reading text types such as informational and literary texts. This quantitative research was based on a sample of 830 adults aged between 19 and 71 years. The study revealed that during their leisure time, men and women had different reading preferences. Men preferred to read more often to gain information, while women were more into reading for the sake of entertainment. Those whose reading preference was for entertainment had a higher ability or reading competence 


\section{A. Dzo’ul Milal et al.}

in literary texts; nevertheless, the individuals who preferred to read for gaining information had positive reading competence in both informational and literary texts.

Considering all those previous studies accessible to the researchers, none of them dealt with the reading preferences of EFL students in Indonesia. This is the niche that this study is trying to cope with. In addition, this current study attempts to foster previous research on the reading preferences of EFL adult students with regard to their gender differences. Even though this study is not investigating specific reading text types, revealing what they read during their leisure time will be very useful and predictive to their reading competence that might facilitate their academic success as well.

\section{Research Methodology}

\subsection{Subjects}

This survey study was intended to reveal the reading preferences in leisure time across genders of EFL students in Indonesia. The subjects who responded to the survey were adult university students, aged 19 - 23 years, studying at the English Department, Sunan Ampel State Islamic University Surabaya, a typical state-managed Islamic university in Indonesia. It was conducted during the pandemic when students were off from campus activities due to semester holidays and the work-from-home pandemic. To collect the data, the researchers sent 700 students a questionnaire through a google form link and requested them to respond. Those who responded were 172 consisting of 47 male and 125 female students representing all students of all semesters $2,4,6$, and 8 .

\subsection{Instruments}

As the instrument, this study employed a questionnaire consisted of closed and open questions. The closed items were about the fixed options, such as whether or not the subjects read and what they prefer to read. The open queries further probe the closed items, like why they read or not read, or why they chose certain options, e.g., digital or printed materials.

\subsection{Data Analysis Procedures}

To analyze the data, the researchers tallied and converted the responses to the closed items into percentages, while those to open questions were analyzed following Miles et al. (2020), viz. i.e., reduced (by selecting the relevant information), displayed (by managing, classifying, and finding relationships), and concluded to summarize the points to be described verbally.

\section{Findings}

Consistent with the research focus, which is unfolding inter-gender variabilities in reading preferences, this part presents the findings including the respondents to the questionnaire, whether and why they read or not read, the preference of digital or printed materials, that of English, Indonesian, or other texts, and their belief about the drive of reading activity.

\subsection{Number of Male and Female Readers}

Concerning whether or not the students spent their leisure time reading, the findings demonstrate that the percentage of all respondents (male and female) who spent their leisure time reading was $74.7 \%$, almost two-thirds of the informants, while those who did not was only $25.3 \%$ (Table 1 ). To probe this issue, the researchers made the comparison of intragenders based on the percentage of the readers. Among the 47 male respondents, those who 
read was $51.06 \%$, and those who did not read was $48.94 \%$. Moreover, among the 125 female respondents, those who read were $82.4 \%$, and those who did not were $17.6 \%$ (Table 1 ). It implies that the percentage of female readers was greater than that of males.

Table 1: Respondents who Read and do not Read Based on Gender Differences

\begin{tabular}{llcccccc}
\hline No. & Respondents & $\begin{array}{c}\text { Number of } \\
\text { M \& F }\end{array}$ & \% & Male & (\%) & Female & (\%) \\
\hline 1. & Who read & 127 & 74.7 & 24 & 51.06 & 103 & 82.4 \\
\hline 2. & Who do not read & 45 & 25.3 & 23 & 48.94 & 22 & 17.6 \\
\hline 3. & Total & 172 & 100 & 47 & 100 & 125 & 100 \\
\hline Note: $M$ = Male; F = Female & & & & & &
\end{tabular}

Note: $M=$ Male; $F=$ Female

\subsection{Reasons for not Reading}

When explored further why they did not read to spend their leisure time, the reasons expressed by the male students were different from that of females as presented in Table 2. Male students do not read mostly because they are busy working, while females do more varied activities. Another different reason between males and females is that females do not read because they help their parents. Some respondents of both genders do not enjoy reading because it is boring and they do not have the books to read.

Table 2: Reasons for not Reading across Genders

\begin{tabular}{|c|c|c|c|c|c|}
\hline No. & Male's reasons for not reading & $\mathrm{N}$ & No. & Female's reasons for not reading & $\mathbf{N}$ \\
\hline 1. & Working & 7 & 1. & Doing other activities: drawing, & 12 \\
\hline 2. & $\begin{array}{l}\text { Doing other activities: editing video, } \\
\text { helping parents, doing what he likes, } \\
\text { watching TV, doing other tasks, } \\
\text { doing sport }\end{array}$ & 6 & & $\begin{array}{l}\text { watching TV, playing games, doing } \\
\text { sport, watching films, making cakes, } \\
\text { doing household tasks, online activities, } \\
\text { social media, writing essays }\end{array}$ & \\
\hline 3. & Don't like reading, too boring to read & 4 & 2. & Helping parents & 4 \\
\hline 4 . & Having no reasons & 3 & 3. & Lazy, don't like it because too boring & 2 \\
\hline 5 . & Social media is more interesting & 1 & 4 . & Working and starting a business & 2 \\
\hline 6. & Having no book to read & 1 & 5. & Having no book to read & 2 \\
\hline
\end{tabular}

Note: $\mathrm{N}=$ number of respondents

\subsection{Materials to Read}

Concerning what they read, $49.6 \%$ of the respondents read social media, such as WhatsApp messages, Facebook, Instagram, and Twitter, $27.3 \%$ read literary works, and $7.2 \%$ read an array of materials. Comparing the gender, there is a tendency that both males and females mostly like to read social media, followed by literary works. Reading reference books is liked by females more than by males, whereas reading mass media is preferred by males more than by females. Both genders also read other materials, but what they read is somewhat different. Males read al-Quran, self-development books, webtoon comics, watch YouTube and Islamic history. In contrast, females watch TV, webtoon, manga, fanfics, google trivial tips, like DIY (Do It Yourself), economic, business blogs, and articles.

\subsection{Purposes of Reading}

When asked about their reading purposes, $54.6 \%$ read to get information, $28.2 \%$ to get pleasure, and $17.2 \%$ to kill time. Both genders have the same tendency; they read for information more than for pleasure. However, when this point is rechecked with another item concerning whether they read literary works or other science books, the data show that they 


\section{A. Dzo'ul Milal et al.}

read literary works more than other science books. Theoretically, reading literary works is for pleasure while referencing books for information. There was an inconsistency in their responses. Although many of them read to obtain information, what they read was literary works. The respondents might not be quite aware of the difference between "for pleasure and "for information."

What seems to be striking is that the number of females who read just to kill time is more than that of males. It is surprising because killing time implies having nothing to do, which females do more. It might also indicate that males tend to do physical activities, like sports or playing games, than females, evidenced by that only fewer of them read to kill time (Videnović et al., 2010).

\subsection{Preferences for Digital or Printed Materials}

About the type of books to read, more respondents prefer reading digital books to printed books, with a percentage of $62 \%$ against $38 \%$. The data show that the rate of females who prefer digital books exceeds that of printed books. In contrast, males like printed books better than e-books. The reasons for their preferences are listed in the following Tables 3 and 4 . In short, they like e-books because they are more practical, more efficient, easier to access, cheaper, more choices, and more up-dated.

The respondents who favor printed books expressed that they like them because they are safer, healthier, and more convenient to the eyes. The books can also be highlighted or given notes. They make them more focused and not easily distracted, or another reason is that it is simply because they have already been purchased and available on their shelves. More details are presented in Table 4 .

Table 3: Reasons for Preferring Digital to Printed Materials

\begin{tabular}{ll}
\hline \multicolumn{1}{c}{ Males } & \multicolumn{1}{c}{ Females } \\
\hline Easily accessible & Easily accessible \\
Economical & Economical \\
Portable & Portable \\
More convenient & More convenient \\
More practical & More practical \& simple \\
Easy to get & Easy to get \\
Have no printed books & Have no printed books \\
More e-books are available & Have more e-books than printed books \\
More efficient & More updated \\
& I have read all of my printed books, so I downloaded new e-books \\
& Just like it, with no reason \\
\hline
\end{tabular}

Table 4: Reasons for Preferring Printed Books to Digital Materials

\begin{tabular}{ll}
\hline \multicolumn{1}{c}{ Males } & \multicolumn{1}{c}{ Females } \\
\hline Have been purchased & Just like printed books more than e-books \\
Can be noted and highlighted & Can be noted and highlighted \\
More effective to get the "feeling" & More fascinating \\
Healthier and safer for the eyes & Healthier and safer for the eyes \\
More comfortable & More comfortable \\
More convenient & More convenient \\
More focused and less distraction & More focused and less distraction \\
Easier to apply & Can exchange with friends \\
To get rid of the gadget & E-books are not complete unless we purchase them. \\
Too many unread books on the shelves & Collecting books is satisfying \\
\hline
\end{tabular}




\subsection{Languages of the Reading Materials}

Since the subjects are the English Department students, it is relevant to reveal what languages (English, Indonesian, or another) the books they read are written in. Reading English books may imply that the students have strong motivation to learn English, as evidenced by their hard effort to practice their target language by reading English books in their spare time. Reading Indonesian materials might indicate their interest in reading. They just want to enjoy their holiday reading to get pleasure or get information without struggling to learn English. In relevance to this, the data reveal that more respondents $(66.9 \%)$ read Indonesian, $28.5 \%$ read English, and $4.6 \%$ other languages.

Table 5: Reasons for Preferring Native Language Readings (Indonesian)

\begin{tabular}{ll}
\hline \multicolumn{1}{c}{ Males } & \multicolumn{1}{c}{ Females } \\
\hline Easier to understand & Easier to understand \\
Indonesian is the mother tongue & Daily language \\
Find more books or sources in Indonesian & Find more books or sources in Indonesian \\
Like to use the language I master better & Don't need to translate \\
Find the translated version & More comfortable \\
Find more local news in Indonesian & More simple \\
My social media mostly use Indonesian & My social media mostly use Indonesian \\
Get used to it & More practical \\
No reason & No reason \\
& No other choice \\
\hline
\end{tabular}

Table 5 shows several reasons why respondents prefer reading Indonesian texts to reading English resources despite their being EFL students. Both male and female respondents agree that they like reading the materials written in Indonesian because they are easier to understand and do not need a translation. Hence, they can understand better and faster. Consistent with the previous finding of what to read, some respondents prefer reading the materials in Indonesian because their social media mostly use Indonesian.

On the other hand, the respondents who prefer reading English resources better than Indonesian ones also mention their varied reasons (Table 6 ). In general, both male and female respondents like reading English for their learning purposes. That is because they want to improve their target language, e.g., to improve vocabulary, reading skills, and knowledge of the current development of linguistics and literature. Others claimed they like English resources because they are better and more interesting than Indonesian, and the stories are also more imaginative. In short, they like English materials because they want to practice using their target language.

Table 6: Reasons for Preferring Target Language Readings (English)

\begin{tabular}{ll}
\hline \multicolumn{1}{c}{ Males } & \multicolumn{1}{c}{ Females } \\
\hline To know the outside world of Indonesia & Just like it \\
English as an international language & As a student of ED [English Department], I'm used to \\
To improve and practice my English knowledge & reading English \\
and skills in terms of vocabulary, & As a student of ED, I'm curious about the new \\
pronunciation, and reading skills & development in linguistics and literature. \\
To maintain my English skills during the & To improve and practice my English knowledge and skills \\
holiday & in terms of vocabulary, pronunciation, and reading skills \\
I like English & Relevant to my major \\
& I find English sources more than Indonesian \\
\hline
\end{tabular}


English sources are better, more interesting, and more imaginative than Indonesian

I get more information in English

I like English

Some of the respondents reported that they prefer materials written not in either English or Indonesian for some reason. They do it because they read Arabic books of religious knowledge; others asserted that they are bored reading English or Indonesian. They need an alternative or to get broader coverage.

\subsection{Factors that Drive to Read}

When the respondents were asked to reflect on the factors that may drive them to read or not to read, most respondents claimed that it is determined by their traits, e.g., diligence or laziness. Some are dictated by the strong or weak learning motivation. Others asserted that it is due to the reading habit since their childhood. The rest of the respondents stated it is because of several other reasons, such as mood, curiosity, topic interest, willingness, parents factor, and hobby (Table 7).

Table 7: Factors that Drive to Read or Not to Read

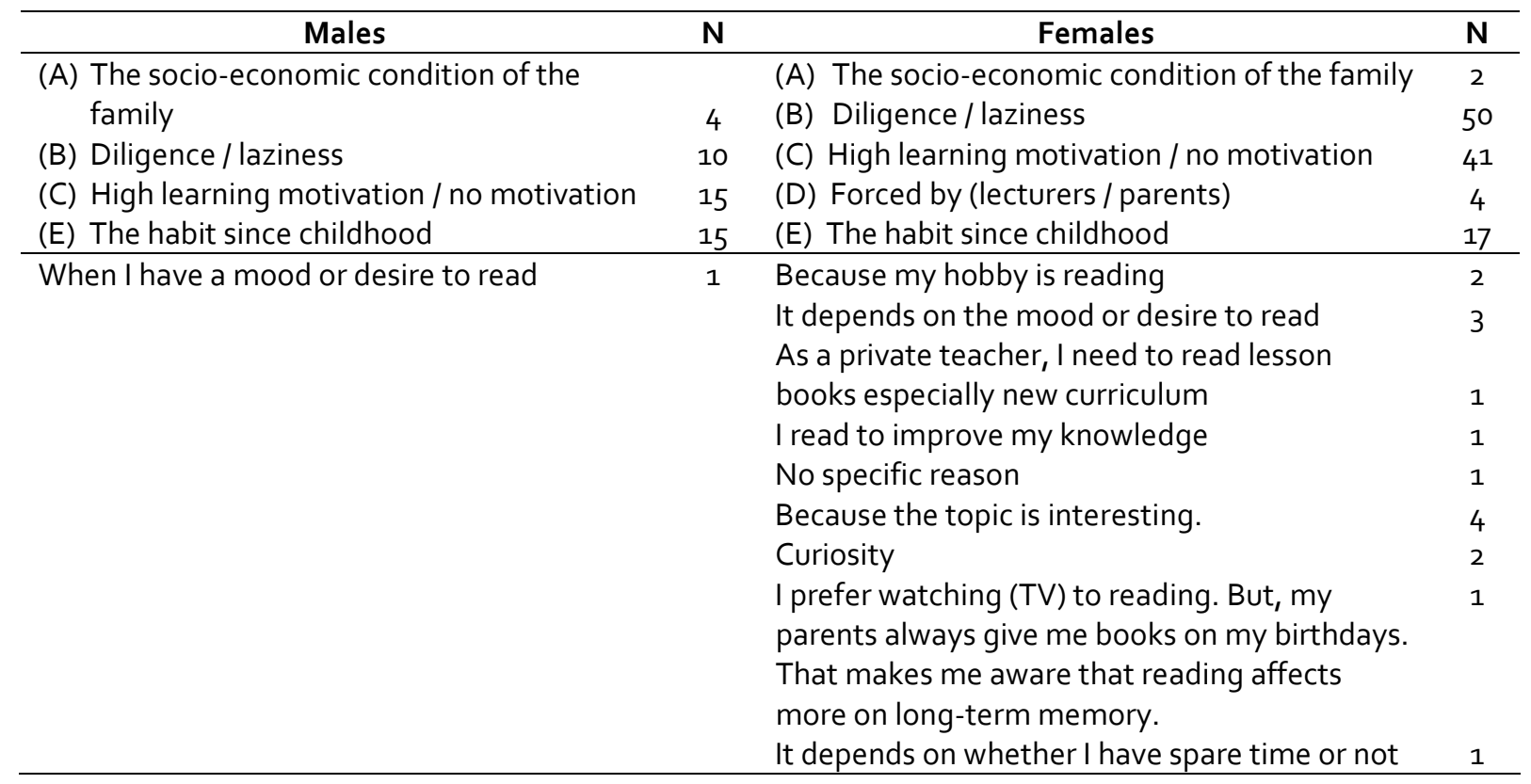

\section{Discussion}

First, comparing the number of respondents across genders, it was found out that the number of female respondents is almost thrice of the males. This finding agrees with Porter \& Whitcomb's (2005) study that says females are more likely to respond to surveys. While the number of Porter \& Whitcomb's female cooperators reaches $66 \%$, the female respondents of the present study is $73 \%$. It may also represent the proportion of the population that consists of girls more than boys. Besides, due to the global pandemic COVID 19 and semester holidays, all students were off from the campus activities. When the google-form questionnaire was sent to them through their WhatsApp groups, some students did not respond or might not have opened it. 
Second, the percentage of female respondents who spend their leisure time reading is higher than that of males. This goes in line with the findings of Loh et al. (2019), who claim that when studying adolescent students in Singapore, they found that more girls like reading better than boys. The difference is that their subjects were adolescents while this study was adults. Since they were all students, however, their reading needs are likely to be comparable. This finding also affirms Videnović et al. ( 2010), who claim that boys tend to enjoy sports and playing games for their leisure time more than girls.

Third, regarding the reasons for not reading, there is some slight divergence between males and females. As mentioned by most of them, males do not read because they are busy working in the workplace, whereas females state that they do not read since they are occupied household tasks. This is also consistent with Scott's (2019) statement related to gender stereotypes, in that "women belong in the home while men work and provide support." Besides, more males than females said that reading is boring, but more females than males admitted that they help their parents. It seems to support Logan \& Johnston's (2009) claim that "girls had better reading comprehension, read more frequently, and had a more positive attitude to reading and school."

Concerning what is read by different genders, the data show that most respondents (male and female) read social media, e.g., WhatsApp, Twitter, Facebook, Instagram. This seems to go in line with the current trend of global advancement in information technology, where people of the world are engulfed in using gadgets to conduct digital communication. Females prefer reading reference books while males like reading mass media. This finding implies that females prefer to read more study-oriented materials while males favor more popular resources.

About the reasons for reading, the data show that most respondents read to get information more than for pleasure. Despite their difference, these two purposes are not necessarily distinguished independently. Reading reference books is naturally intended to convey information, while reading literary works (e.g., novels and short stories) is for pleasure. However, EFL learners likely read novels or short stories not only for pleasure but also to study their generic structure or to analyze their intrinsic elements. Thus, it is to get information rather than for pleasure. This is supported by Indrayadi (2021), who demonstrates that students' reasons for reading are affected mainly by external motivations such as gaining information and finishing the reading materials for assignments. That also applies to reading newspapers, magazines, social media. It can be both or either for information or pleasure, depending on the contents of the read texts.

Another purpose of their reading activity is just to kill time. This is a bit surprising because, as college students, the respondents should have been busy doing study-related tasks. They are not idle, having nothing to do, hence reading is not just to kill time. It should have been intended to improve their attitude, knowledge, and skills. The reading materials should have been selected for their study purposes, and the reading activity is done purposively based on a strictly programmed schedule.

The data also show that more respondents prefer e-books to printed books. The reason underlying such a preference is that digital materials are more practical, more efficient, easier to access, cheaper, more choices, and more up-dated. The preference for printed resources, on the other hand, is that they are safer, healthier, and more convenient to the eyes, could 


\section{A. Dzo'ul Milal et al.}

be highlighted or given notes, they become more focused and not easily distracted. E-books are indeed more practical and efficient in the sense that carrying just one gadget is enough to access thousands of materials. Many e-materials are free of charge, thus making them cheaper and accessible. The main weakness is related to its destructive impact on the readers' health of the eyes. Such a negative impact is absent and thus becoming the superiority of printed books. Another weakness of using digital resources is that the readers can easily be distracted, especially when using a mobile phone. They are often distracted by notifications on social media. The absence of such distraction becomes the strength of printed books over electronic media because the readers can be more focused. Besides, printed materials can be highlighted and given notes. This benefits the visual learners because it facilitates tracking, speeding up catching the points, and reinforcing their memory. The positive and negative sides of e-books are also supported by Huang (2013), who observed the learners' perception towards e-books which shows that the portability and availability of e-books make the digital resources superior to the printed ones; however, the predisposition of e-books to eyestrain results to objection to reading e-books.

Despite being EFL learners, more respondents prefer reading the materials in Indonesian (their native language) to English (their target language). It corresponds with Mikulec \& Vuić's (2019) research, which indicated that foreign language learners have better reading comprehension in their native language than that in their target language. Although that might not be ideal for improving their target language skills, reading native language materials is beneficial to increase their literacy skills and broaden their horizon of knowledge. Their claim that reading Indonesian materials is easier may imply some points. First, their English competence has not been mature, and they are still struggling to use it. Second, they want to enjoy their leisure time with ease more than doing more energy-consuming activities. Third, they think that reading English is a burden and their motivation to improve their English skills is not as strong as their eagerness to gain information instantly. This seems to be against Renandya \& Jacobs's (2002) suggestion to encourage extensive reading to improve target language skills. This is also supported by Chow et al. (2017), who unraveled that foreign language motivation and learning strategies contribute to the performance of foreign language reading.

Relevant to the factors that drive the reading activity, the respondents mention several aspects, namely the personal aspects, such as motivation and curiosity about the reading materials, the habit since childhood, the personal condition, e.g., diligence or laziness, and the personal mood to read. The textual aspect is also a determinant of the reading activity. That means whether or not the contents or topics of the texts are interesting, relevant, and valuable to the readers. It is in line with Salikin et al. (2017), who revealed that topic relevance and interest contribute to the individuals' reading desire. Furthermore, accessibility can also drive someone to read, such as the availability of the reading materials, including the ease of access, cheap to purchase, ease to find and to download.

In an EFL context, learners' frequency of reading activities needs to be raised in intensive and extensive readings. Those findings implicate that, to promote learners' reading habits, teachers need to consider the reading materials to be exposed to the learners, be they digital or printed resources, whether their contents are relevant, comprehensible, and interesting, and if the reading assignments are sufficiently given to intensify the students' use of their leisure time. 
These findings implicate that the policy designers who want to promote literacy can consider those aspects to provide conducive reading environments. Especially for EFL teachers who want to motivate their students to do more reading activities during their work-from-home, they should consider not only the reading contents which are interesting and relevant but also the types of resources that are accessible in the forms of digital or printed materials. Furthermore, reading tasks should be made pleasurable so that students do not feel it as a psychological burden but as enjoyment that they will love doing it.

\section{Conclusion}

This study reveals several points. Towards a free-response survey, females tend to be more responsive than males. On leisure-time reading, the female respondents have a higher percentage who spend their spare time reading than males. The reason males do not read a lot is that they are busy working part-time jobs, while females tend to be more occupied with household chores. The advanced information technology undoubtedly affects the preferences for reading sources as most respondents, both males and females, like to read social media more than other materials. Female respondents tend to prefer selfdevelopment-oriented materials while males like more popular resources. Moreover, despite the respondents' being EFL learners, most of them prefer reading native language (Indonesian) materials to target language (English) ones. It implies that their target language learning enthusiasm is not as strong as their motivation to enjoy themselves reading for pleasure. In addition to that, the main reason for both gendered respondents' choosing ematerials is its practicality and accessibility. For the printed ones, it is mainly its safety for the eyes and readers' freedom from distractions.

However, this study is still far from perfection. Because the data in this study were collected through a questionnaire, there is a possibility that the respondents did not respond to the questions according to the actual conditions. To handle this, the respondents had been provided with some directions to respond to the questionnaire truthfully, and the responses were based on the assumption of their honesty. Therefore, the data were assumed to be valid as in the actual circumstances. Furthermore, this study is also limited to the findings of reading preferences across genders among EFL college students. Thus, further studies regarding reading preferences across ages or English proficiency levels are recommended to fill the gap of this study.

\section{References}

Aharony, N., \& Bar-llan, J. (2018). Students' academic reading preferences: An exploratory study. Journal of Librarianship and Information Science, 50(1), 3-13. https://doi.org/10.1177/0961000616656044

Akbari, H., Ghonsooly, B., Ghazanfari, M., \& Shahriari, H. (2017). Attitude toward reading: L1 or L2 or both. SAGE Open, 7(3), 1-10. https://doi.org/10.1177/2158244017717303

Alakawi, K. M. (2017). Vocabulary Strategies and Bridging the Gap from Learning to Read to Reading to Learn. Journal of Language and Education, 3(4), 60-72. https://doi.org/10.17323/2411-7390-2017-3-4-60-72

Chen, C.-N., Chen, S.-C., Chen, S.-H. E., \& Wey, S.-C. (2013). The effects of extensive reading viae-books on tertiary level EFL students' reading attitude, reading comprehension and vocabulary. Nation, 12(2), 303-312. http://www.tojet.net/articles/v12i2/12228.pdf 
Chow, B. W. Y., Chiu, H. T., \& Wong, S. W. L. (2017). Anxiety in reading and listening English as a foreign language in Chinese undergraduate students. Language Teaching Research, 22(6), 719-738. https://doi.org/10.1177/1362168817702159

Delfi, S., \& Yamat, H. (2017). Extensive reading in developing English competency for Indonesian EFL learners majoring in English. Indonesian Journal of English Language Teaching and Applied Linguistics, 1(2), 153-164. https://doi.org/http://dx.doi.org/10.21093/ijeltal.vii2.20

Ghanbari, M., \& Marzban, A. (2014). Effect of Extensive Reading on Incidental Vocabulary Retention. Procedia - Social and Behavioral Sciences, 116(2014), 3854-3858. https://doi.org/10.1016/j.sbspro.2014.01.854

Huang, H.-C. (2013). E-reading and e-discussion: EFL learners' perceptions of an e-book reading program. Computer Assisted Language Learning, 26(3), 258-281. https://doi.org/10.1080/o9588221.2012.656313

Indrayadi, T. (2021). Indonesian EFL learners' reading motivation. Indonesian Journal of English Language Teaching and Applied Linguistics, 5(2), 335-346. https://doi.org/10.21093/ijeltal.v5i2.745

Iwahori, Y., High, N., \& Japan, S. (2008). Developing reading fluency: A study of extensive reading in EFL. Reading in A Foreign Language, 20(1), 70-91. http://nflrc.hawaii.edu/rfl

Karim, N. S. A., \& Hasan, A. (2007). Reading habits and attitude in the digital age: Analysis of gender and academic program differences in Malaysia. Electronic Library, 25(3), 285-298. https://doi.org/10.1108/02640470710754805

Kurata, K., Ishita, E., Miyata, Y., \& Minami, Y. (2017). Print or digital? Reading behavior and preferences in Japan. Journal of the Association for Information Science and Technology, 68(4), 884-894. https://doi.org/10.1002/asi.23712

Lee, J., Schallert, D. L., \& Kim, E. (2015). Effects of extensive reading and translation activities on grammar knowledge and attitudes for EFL adolescents. System, 52(2015), 38-50. https://doi.org/10.1016/j.system.2015.04.016

Lin, C. C. (2014). Learning English reading in a mobile-assisted extensive reading program. Computers and Education, 78(2014), 48-59. https://doi.org/10.1016/j.compedu.2014.05.004

Logan, S., \& Johnston, R. (2009). Gender differences in reading ability and attitudes: Examining where these differences lie. Journal of Research in Reading, 32(2), 199-214. https://doi.org/10.1111/j.1467-9817.2008.01389.x

Loh, C. E., Sun, B., \& Majid, S. (2019). Do girls read differently from boys? Adolescents and their gendered reading habits and preferences. English in Education, 54(2), 174-190. https://doi.org/10.1080/04250494.2019.1610328

Long, D., \& Szabo, S. (2016). E-readers and the effects on students' reading motivation, attitude and comprehension during guided reading. Cogent Education, 3(1), 1-11. https://doi.org/10.1080/2331186X.2016.1197818

McLean, S., \& Rouault, G. (2017). The effectiveness and efficiency of extensive reading at developing reading rates. System, 70(2017), 92-106. https://doi.org/10.1016/j.system.2017.09.003

Mizrachi, D., Salaz, A. M., Kurbanoglu, S., \& Boustany, J. (2018). Academic reading format preferences and behaviors among university students worldwide: A comparative survey analysis. PLOS ONE, 13(5), 1-32. https://doi.org/10.1371/journal.pone.0197444

Morrison, F. (2017, April 29). Do men and women read differently? . Readability Australia. 
https://readability.com.au/2017/04/29/do-men-and-women-read-differently/

Mullis, I. V. S., Martin, M. O., Foy, P., \& Hooper, M. (2017). ePIRLS 2016: International Results in Online Informational Reading. TIMSS \& PIRLS International Study Center.

OECD. (2013). The survey of adult skills: Reader's companion. In The Survey of Adult Skills. OECD Publishing. https://doi.org/10.1787/9789264204027-en

Renandya, W. A., \& Jacobs, G. M. (2002). Extensive Reading: Why Aren't We All Doing It? In J. C. Richards \& W. A. Renandya (Eds.), Methodology in Language Teaching: An Anthology of Current Practice (pp. 295-302). Cambridge University Press.

Salikin, H., Zulfiqar Bin-Tahir, S., Kusumaningputri, R., \& Yuliandari, D. P. (2017). The Indonesian EFL learners' motivation in reading. English Language Teaching, 10(5), 81-90. https://doi.org/10.5539/elt.v10n5p81

Schiefele, U., Schaffner, E., Möller, J., Wigfield, A., Nolen, S., \& Baker, L. (2012). Dimensions of reading motivation and their relation to reading behavior and competence. Reading Research Quarterly, 47(4), 427-463. https://doi.org/10.1002/RRQ.030

Scott, S. (2019). Gender Differences Within the Workplace. https://smallbusiness.chron.com/gender-differences-within-workplace-10512.html

Singer, L. M., \& Alexander, P. A. (2017). Reading across mediums: Effects of reading digital and print texts on comprehension and calibration. Journal of Experimental Education, 85(1), 155-172. https://doi.org/10.1080/00220973.2016.1143794

Stokmans, M. J. W. (1999). Reading attitude and its effect on leisure time reading. POETICS, 26(4), 245-261. https://doi.org/10.1016/S0304-422X(99)00005-4

Suk, N. (2016). The effects of extensive reading on reading comprehension, reading rate, and vocabulary acquisition. Reading Research Quarterly, o(0), 1-7. https://doi.org/10.1002/rrq.152

Swalander, L., \& Taube, K. (2007). Influences of family based prerequisites, reading attitude, and self-regulation on reading ability. Contemporary Educational Psychology, 32(2007), 206-230. https://doi.org/10.1016/j.cedpsych.2006.01.002

Thums, K., Artelt, C., \& Wolter, I. (2021). Reading for entertainment or information reception? Gender differences in reading preferences and their impact on text-typespecific reading competences in adult readers. European Journal of Psychology of Education, 36, 339-357. https://doi.org/10.1007/s10212-020-00486-1

Videnović, M., Pešić, J., \& Plut, D. (2010). Young people's leisure time: Gender differences. Psihologija, 43(2), 199-214. https://doi.org/10.2298/PSl1002199V

Zhang, Y., \& Kudva, S. (2014). E-books versus print books: Readers' choices and preferences across contexts. Journal of the Association for Information Science and Technology, 65(8), 1695-1706. https://doi.org/10.1002/asi.23076 